\title{
CONCOMITANT HPLC ANALYSIS OF ADAPALENE AND NADIFLOXACIN IN THE PRESENCE OF GLYCOLIC ACID
}

\author{
SILVIA IMRE ${ }^{1}$, STELA MARIANA AL HUSSEIN ${ }^{1,2} *$, ANDREEA PASCU ${ }^{1}$, LAURA ELENA \\ OLTEAN (GLIGA) ${ }^{1,3}$, MARIA-TITICA DOGARU ${ }^{1}$, HAMIDA AL HUSSEIN ${ }^{4}$, DANIELA-LUCIA \\ MUNTEAN $^{1}$, AMELIA TERO-VESCAN ${ }^{1}$ \\ ${ }^{1}$ Faculty of Pharmacy, University of Medicine, Pharmacy, Sciences and Technology, 38 Gheorghe Marinescu Street, Târgu \\ Mureş, 540139, Romania \\ ${ }^{2}$ Dr Amer Clinic SRL, 65 Corneşti Street, Târgu Mureş, 540077, Romania \\ ${ }^{3}$ Faculty of Pharmacy, "Iuliu Haţieganu” University of Medicine and Pharmacy, 4 Pasteur Street, Cluj-Napoca, 400349, \\ Romania \\ ${ }^{4}$ Faculty of Medicine, University of Medicine, Pharmacy, Sciences and Technology, 38 Gheorghe Marinescu Street, Târgu \\ Mureş, 540139, Romania
}

*corresponding author: stela.alhussein@yahoo.com

Manuscript received: March 2019

\begin{abstract}
Reversed phase HPLC-UV is the most common analytical method applied in pharmaceutical analysis, but there are cases when its versatility is challenged, such as simultaneous separation of analytes with very different polarity and lipophilicity. A fast HPLC-UV method for the simultaneous determination of nadifloxacin (NDX) and adapalene (ADP) in the presence of glycolic acid (GA) was developed and analytical performances of the method were verified. Different alkane-type reversed phases ( $\mathrm{RP}_{8}$ and $\mathrm{RP}_{18}$ columns, with different lengths and particle sizes) and different mobile phases were tested. Finally, a C18 column ( $33 \times 4.6 \mathrm{~mm}, 3 \mu \mathrm{m})$ and a mobile phase consisted of $15 \mathrm{mM}$ orthophosphoric acid solution and acetonitrile were selected. Determinations were performed with a run time of 4 minutes. The method was linear, accurate and precise over the selected concentration ranges of ADP and NDX. The developed method can be used for rapid quantification ADP and NDX without GA interference for in vitro release studies from topical formulations, through different types of diffusion membranes.
\end{abstract}

\section{Rezumat}

HPLC-UV în fază inversă este cea mai folosită metodă în analiza farmaceutică, dar sunt anumite situații în care versatilitatea sa este pusă sub semnul întrebării, cum este cazul separării simultane a compuşilor cu polaritate şi lipofilie foarte diferite. În acest studiu a fost dezvoltată și s-a verificat performanța analitică a unei metode HPLC cu detecție UV pentru analiza simultană a nadifloxacinei (NDX) și a adapalenului (ADP) în prezența acidului glicolic (GA). Au fost testate diferite faze mobile şi faze staţionare (coloane $\mathrm{RP}_{8}$ și $\mathrm{RP}_{18}$ de diferite dimensiuni şi mărimi ale particulelor). În final a fost selectată $\mathrm{o}$ coloană C18 (33 x 4,6 mm), cu dimesiunea particulelor de $3 \mu \mathrm{m}$, iar faza mobilă a fost formată din acid ortofosforic $15 \mathrm{mM}$ şi acetonitril. Timpul de analiză a fost sub 4 minute. Metoda dezvoltată a fost liniară, exactă şi precisă pe domeniile de concentrație alese pentru ADP şi NDX. Această metodă permite determinarea cantitativă rapidă a NDX și a ADP fară interferențe datorate GA în studii de cedare prin diferite tipuri de membrane din formulări topice cu cele 3 componente.

Keywords: adapalene, nadifloxacin, glycolic acid, HPLC, topical formulations

\section{Introduction}

Acne is a chronic inflammatory disease of pilosebaceous skin units, with multifactorial aetiology $[7,18]$ and characterized by presence of comedones, papules, pustules, nodules, cysts, which might result in permanent scars [3]. Besides physical trauma (hyper or hypopigmentation, scar formation or skin disfigurement), acne has many psychosocial implications, affecting especially adolescents' self-esteem and selfconfidence [10].

There are several main etiological factors implicated in acne pathogenesis: the increased sebum production (frequently induced by testosterone secretion), irregular follicular desquamation (abnormal desquamated corneocytes are gathered in the sebaceous follicle along with other lipids), bacterial proliferation (Propionibacterium acnes determining local skin inflammation by producing pro-inflammatory mediators) and inflammation of the affected area [6]. Acne treatment includes systemic administration of retinoids, antibiotics or oral contraceptives, physical treatment, diet and nevertheless topical treatment. Topical treatment of acne vulgaris has the advantage of targeting directly the affected area and decrease of systemic absorption; literature data confirm that the combination therapy 
proved to be more effective than monotherapy with antimicrobial agents or retinoids [1, 11, 12].

Considering the complex acne aetiology and the diversification of anti-acne products on the pharmaceutical market, among other drugs, nadifloxacin (NDX), adapalene (ADP) and glycolic acid (GA) are compounds with marketing authorization for acne vulgaris but are only used as monotherapy [13]. NDX is a topical fluoroquinolone antibiotic approved for the treatment of acne vulgaris in Japan and Europe since 1993, with a minimal inhibitory concentration 50 and 90 against $P$. acnes twofold lower than ciprofloxacin $[2,11,12]$. ADP is a retinoid with similar pharmacologic profile to tretinoin, but with better photochemical stability, available on pharmaceutical market as a topical combination ADP/benzoyl peroxide gel $0.1 \% / 2.5 \%$ or as monotherapy ADP $0.1 \%$ gel. ADP is efficient in acne atrophic scarring caused by dermal matrix loss [14]. GA is an alpha-hydroxy acid widely used in cosmetic formulations to improve drug permeation and as a superficial peeling agent. In addition, GA ameliorates the appearance of keratosis and acne by reducing the cohesion of the corneal layer of the skin [4]. Low concentrations of GA have an anti-inflammatory effect by reducing UVB-induced inflammatory cytokines while high concentrations produce a toxic effect by skin-cell apoptosis and DNA damage [17].

The three components are individually used or in combination with benzoyl peroxide as active pharmaceutical ingredients in topical anti-acne products. Extensive clinical trials recommend the use of fixed combination gels to benefit from the synergistic effect of a topical antibiotic with a retinoid and a superficial peeling agent, as acne is a multifactorial pathology involving abnormal bacterial proliferation, inflammation of the skin with consequent change in its permeability [9]. GA is used in cosmetic products for acne treatment in concentrations over 3\% therefore it can interfere when active compounds as NDX or ADP have to be analysed by analytical methodologies with low specificity.

The aim of the present study was to develop a HPLC method for simultaneous separation of the three selected analytes, a challenge for the analyst as the three substances present different chemical polarity: GA is a small molecule with high polarity and poor retention on non-polar stationary phases [5]; ADP is a highly lipophilic compound, practically insoluble in water and ethanol, soluble in dimethyl-sulfoxide and in tetrahydrofuran and with high retention in reversed phase HPLC [15]; NDX presents a typical reversed HPLC behaviour [16]. Up to now, there are no published studies regarding simultaneous separation of NDX and ADP in the presence of GA by HPLCUV/VIS, a method that can be further applied for quantification of in vitro release of the three active pharmaceutical ingredients from topical preparations.

\section{Materials and Methods}

Reagents. All standards and reagents were of analytical purity and were obtained as follows: NDX was purchased from Sigma Aldrich, while ADP and GA were purchased from Fluka Analytical. Acetonitrile and methanol were obtained from Sigma Aldrich, tetrahydrofuran, phosphoric acid, potassium dihydrogen phosphate, tetrabutylammonium hydroxide and ammonia were purchased from Merck. Distilled, deionized water was produced by a Direct Q-5 Millipore water system.

Standard solutions. Stock solutions of GA and NDX were prepared by dissolving the proper amount in acetonitrile, while for ADP, a mixture of acetonitrile and tetrahydrofuran 90:10 (v/v) was used. The working solutions were obtained as follows: five working solutions of $\operatorname{NDX}(1,10,20,100$ and $200 \mu \mathrm{g} / \mathrm{mL})$ by diluting specific volumes of stock solution with acetonitrile; five working solutions of $\operatorname{ADP}(1,2.5,5$, 15 and $35 \mu \mathrm{g} / \mathrm{mL}$ ) by diluting the stock solution with the acetonitrile and tetrahydrofuran 90:10 (v/v) mixture. Accuracy and precision of the method were verified using five different levels of concentration, including $1 \mu \mathrm{g} / \mathrm{mL}$ as a limit of quantification for both NDX and ADP.

Chromatographic system and conditions. Separations were performed on an Agilent Technologies 1100 series HPLC system equipped with a quaternary pump, thermostatic autosampler, column thermostat, UVVIS detector. Several classic chromatographic columns were tested (C8 and $\mathrm{C} 18$ with different lengths and particle sizes) but also columns with special mechanism of interaction (Kinetex C18 and Luna HILIC), as presented in Table I. Finally, the separation of NDX and ADP was performed on a Phenomenex Luna C18 $(33 \times 4.6 \mathrm{~mm})$ column with the particle size of $3 \mu \mathrm{m}$. The mobile phase consisted of $15 \mathrm{mM}$ orthophosphoric acid solution (solvent $\mathrm{A}$ ) and acetonitrile (solvent B) in a gradient elution as follows: 0 to 1 minute, the ratio of the two solvents was 50:50 (A:B), 1 to 2 minutes gradient changed to $10: 90(\mathrm{~A}: \mathrm{B})$ and was maintained up to 3.9 minutes. By the $4^{\text {th }}$ minute, gradient was changed to the initial composition of 50:50 (A:B) and was maintained for 2 minutes for column re-equilibration. Analysis was performed at $40^{\circ} \mathrm{C}$ with a flow rate of $1.5 \mathrm{~mL} / \mathrm{min}$, injection volume of $10 \mu \mathrm{L}$ and the wavelength was set at $321 \mathrm{~nm}$.

Performances of the analytical method

Linearity of the method was demonstrated by triplicate analysis of five different concentrations of NDX and ADP. A linear correlation between chromatographic peak areas and concentrations was set as primary criteria for linearity, as well as a regression coefficient higher than 0.999 .

Five series of standard solutions, with 5 levels of concentration for each of them (the concentration 
FARMACIA, 2019, Vol. 67, 6

domains being $1-200 \mu \mathrm{g} / \mathrm{mL}$ NDX and $1-35 \mu \mathrm{g} / \mathrm{mL}$ ADP) were prepared and analysed. To verify precision and accuracy, two levels of concentrations with five replicates were used. The lower limit of quantification was tested for both substances at $1 \mu \mathrm{g} / \mathrm{mL}$.

Precision of the method was evaluated by the relative standard deviation (RSD\%) of replicate analysis, the acceptance limit being set at $2.0 \%$.

Accuracy of the method was assessed by mean recovery for standard working concentrations analysed in triplicate, the acceptance limits being set between $95.0 \%$ and $105.0 \%$.

Applicability of the method

The method was tested for the in vitro released studies of NDX and ADP from three newly developed topical products containing NDX, ADP and GA formulated as hydrogels with hydroxypropylmethyl cellulose (HPMC) and hydroxyethyl cellulose (HEC) and an oil-in-water cream, respectively. The experiments were performed using a system of 6 Franz Diffusion Cells and two types of diffusion membranes: a synthetic dialysis membrane and human separated epidermis. The study was approved by The Ethics Committee of the former University of Medicine and Pharmacy from Târgu Mureş, Romania, no. 45/2016 [1].

\section{Results and Discussion}

The main challenges for method developing were: GA presents a low retention in RP-HPLC and a low and non-specific UV absorbance, ADP is highly retained in RP-HPLC, while only NDX presents a classical behaviour in RP-HPLC (suitable retention time at moderate concentration of organic modifier in the mobile phase).

Simultaneous separation of GA, NDX and ADP. There are no literature data regarding simultaneous separation of GA, NDX and ADP by HPLC-UV/VIS $[15,16]$. Considering the physicochemical properties of the three substances, reversed phase chromatography is a proper separation method for NDX, but not for a highly polar compound (GA) or a highly lipophilic compound (ADP). The preliminary GA separation attempts were performed on columns with different technologies (Table I) by using as mobile phase a mixture of acetonitrile, methanol and water at different $\mathrm{pH}$ values, the wavelength being set at $210 \mathrm{~nm}$ at which all three compounds absorb significantly. In order to increase the retention on a reversed phase column and decrease ionization of $\mathrm{GA}$, a $\mathrm{pH}$ lower than the pKa value of GA was selected.

Table I

Cumulative results of GA separation assays at $30^{\circ} \mathrm{C}$

\begin{tabular}{|c|l|l|c|}
\hline No. & \multicolumn{1}{|c|}{ Columns characteristics } & \multicolumn{1}{|c|}{ Mobile phase components } & Results \\
\hline 1 & Symmetry C8, $150 \times 4.6 \mathrm{~mm}, 5 \mu \mathrm{m}$ (porous particles) & $\begin{array}{l}\mathrm{A}-\mathrm{KH}_{2} \mathrm{PO}_{4} 15 \mathrm{mM}, \mathrm{pH}=2.8 \\
\mathrm{~B}-\text { Acetonitrile or methanol }\end{array}$ & $\mathrm{t}_{\mathrm{R}}=\mathrm{t}_{0}$ \\
\hline 2 & Kinetex C18, $150 \times 4.6 \mathrm{~mm}, 2.6 \mu \mathrm{m}$ (core shell particles) & $\begin{array}{l}\mathrm{A}-\mathrm{KH}_{2} \mathrm{PO}_{4} 15 \mathrm{mM}, \mathrm{pH}=2.8 \\
\mathrm{~B}-\text { Acetonitrile or methanol }\end{array}$ & $\mathrm{t}_{\mathrm{R}}=\mathrm{t}_{0}$ \\
\hline 3 & Luna HILIC, $100 \times 2 \mathrm{~mm}, 2.6 \mu \mathrm{m}$ (hydrophilic interaction) & $\begin{array}{l}\mathrm{A}-\mathrm{KH}_{2} \mathrm{PO}_{4} 15 \mathrm{mM}, \mathrm{pH}=2.8 \\
\mathrm{~B}-\text { Acetonitrile }\end{array}$ & $\mathrm{t}_{\mathrm{R}}=\mathrm{t}_{0}$ \\
\hline 4 & Gemini NX C18, $50 \times 2 \mathrm{~mm}, 5 \mu \mathrm{m}$ (stable at very low $\mathrm{pH})$ & $\begin{array}{l}\mathrm{A}-\mathrm{H}_{3} \mathrm{PO}_{4} 25 \mathrm{mM} \\
\mathrm{B}-\mathrm{Acetonitrile}\end{array}$ & $\mathrm{t}_{\mathrm{R}}=\mathrm{t}_{0}$ \\
\hline 5 & Zorbax Extend C18, $250 \times 4.6 \mathrm{~mm}, 5 \mu \mathrm{m}$ (porous particles) & $\begin{array}{l}\mathrm{A}-\mathrm{H}_{3} \mathrm{PO}_{4} 15 \mathrm{mM} \\
\mathrm{B}-\mathrm{Acetonitrile}\end{array}$ & $\mathrm{k}^{\prime}=0.22$ \\
\hline
\end{tabular}

As it can be seen from Table I, GA's peak was observed at the non-retained compound time $t_{0}$, except the experiment performed under the conditions no. 5 (HPLC method 1) when a slightly separation was observed (Figure 1). The elution gradient used in this case was: 0 - 3 min $98 \% \mathrm{~A} ; 3-11 \min 98 \% \mathrm{~A} \rightarrow 10 \%$; $11-24 \min 10 \% \mathrm{~A} ; 24-25 \min 10 \% \mathrm{~A} \rightarrow 98 \% \mathrm{~A}$; 25 - 30 min $98 \% \mathrm{~A}$, where $\mathrm{A}-\mathrm{H}_{3} \mathrm{PO}_{4} 15 \mathrm{mM}$, B acetonitrile. Despite that retention time $t_{R}$ of GA is close to dead time $t_{0}$, the analysis of the three analytes in these conditions allowed simultaneous separation of GA, NDX and ADP from simple matrix such as buffers used for in vitro release studies (Figure 2). However, the HPLC method 1 was not further investigated due to the lowest limit of quantification of $40 \mu \mathrm{g} / \mathrm{mL}$ for GA (calculated to ten times signal to noise ratio) which was not sensitive enough for release determinations from topical preparations.

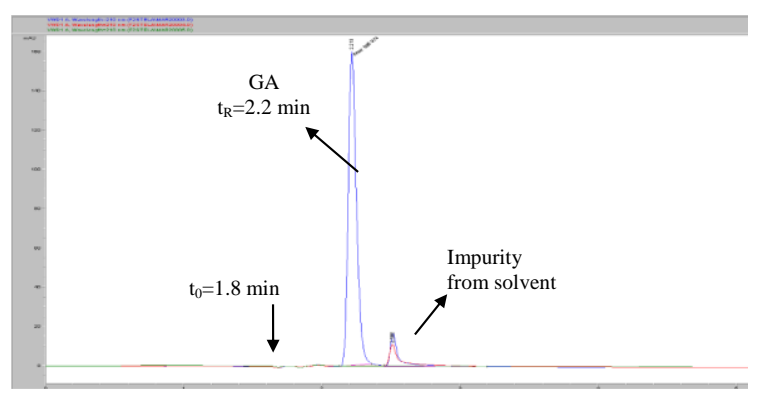

Figure 1.

Specificity of GA separation - HPLC method 1 .

Overlaid chromatograms of a $1000 \mu \mathrm{g} / \mathrm{mL}$ GA solution in acetonitrile (a), solvent acetonitrile (b) and in vitro release matrix phosphate buffer $\mathrm{pH} 5$ (c) 


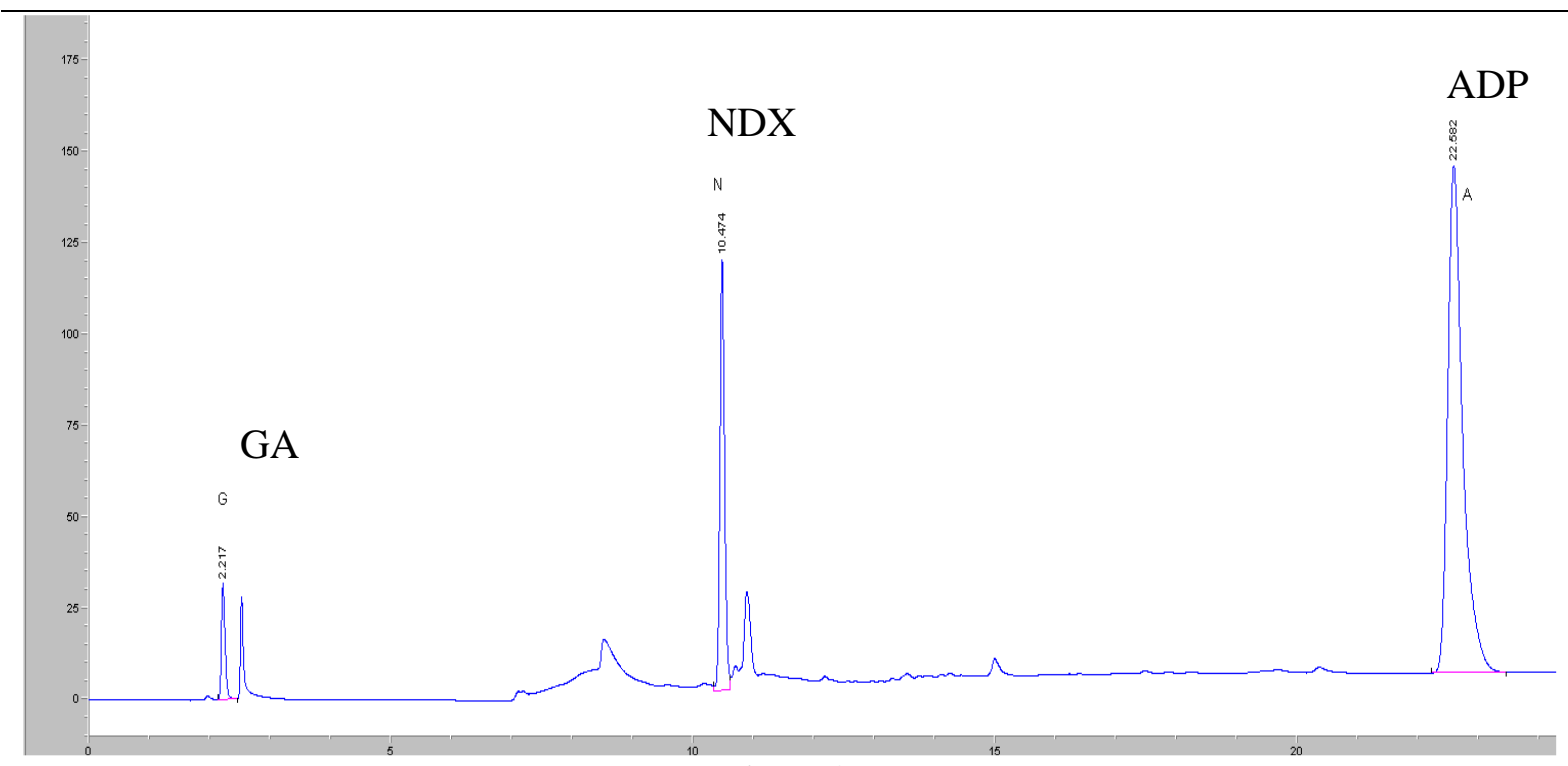

Figure 2.

Chromatogram of a mixture of $200 \mu \mathrm{g} / \mathrm{mL}$ GA, $10 \mu \mathrm{g} / \mathrm{mL}$ NDX and $40 \mu \mathrm{g} / \mathrm{mL}$ ADP in acetonitrile/tetrahydrofuran mixtures - HPLC method 1

Previous assays for GA chemical derivatisation with benzoyl chloride in order to decrease polarity and increase UV absorptivity did not bring convincing results. Therefore, a method for rapid NDX and ADP determination was further developed and tested (HPLC method 2), by using a mobile phase consisting of a mixture of acetonitrile and phosphoric acid 15 $\mathrm{mM}$ in a gradient elution on a mid-bore $\mathrm{C} 18$ column. The temperature was increased to $40^{\circ} \mathrm{C}$ for peak shape improvement and the detection was shifted to $321 \mathrm{~nm}$, a more specific wavelength at which both NDX and ADP have good spectral absorption. The complete conditions are presented in Material and methods chapter. Due to the high content of acetonitrile in the mobile phase, GA is not retained and the proposed method is suitable for simultaneous determination of ADP and NDX in the presence of GA in samples.

Performances of the proposed HPLC method 2 for simultaneous separation of NDX and ADP

Specificity studies. The HPLC method 2 presented a good specificity against the sample matrix substances (phosphate buffer and ethanol) and other matrix compounds in the samples obtained during releasing studies from topical preparations with ADP, NDX and GA. GA eluted with the mobile phase and does not have specific absorption at $321 \mathrm{~nm}$. A series of chromatograms of five standard mixtures of NDX and ADP is presented in Figure 3. The retention time for NDX was of $0.41 \mathrm{~min}$ (capacity factor $\mathrm{k}^{\prime}=1.06$ ) and $3.52 \mathrm{~min}$ for ADP (capacity factor $\mathrm{k}^{\prime}=16.6$ ).

Linearity. As presented in Table II, the method was linear over the selected concentration ranges for both NDX and ADP, with the determination coefficients $\mathrm{R}^{2}>0.9999$ and residual values randomly dispersed within the range $\pm 2.0 \%$. The lower limit of quantification for the two substances corresponds to a concentration of $1.0 \mu \mathrm{g} / \mathrm{mL}$. The lowest limits of quantification were $0.19 \mu \mathrm{g} / \mathrm{mL}$ for NDX and 0.10 $\mu \mathrm{g} / \mathrm{mL}$ for ADP (at ten times signal-to-noise ratio), respectively, and the limits of detection were 0.05 $\mu \mathrm{g} / \mathrm{mL}$ for NDX and $0.03 \mu \mathrm{g} / \mathrm{mL}$ for ADP (at three times signal-to-noise ratio).

Table II

Linearity results for NDX and ADP

\begin{tabular}{|c|c|c|c|c|c|c|c|}
\hline \multicolumn{4}{|c|}{ NDX linearity studies } & \multicolumn{4}{|c|}{ ADP linearity studies } \\
\hline $\mathrm{c}(\mu \mathrm{g} / \mathrm{mL})$ & Average area $(n=5)$ & $\mathrm{RSD} \%$ & Residual standard & $\mathrm{c}(\mu \mathrm{g} / \mathrm{mL})$ & Average area $(n=5)$ & $\mathrm{RSD} \%$ & Residual standard \\
\hline 1 & 20.70 & 1.98 & -0.64 & 1.0 & 17.34 & 1.00 & -0.56 \\
\hline 10 & 175.06 & 1.85 & 0.91 & 2.5 & 46.14 & 1.64 & 1.10 \\
\hline 20 & 316.83 & 1.00 & 0.55 & 5.0 & 87.52 & 0.48 & -1.20 \\
\hline 100 & 1463.46 & 1.51 & -1.44 & 15.0 & 267.93 & 0.59 & 0.97 \\
\hline 200 & 2961.80 & 0.12 & 0.62 & 35.0 & 621.39 & 0.14 & -0.31 \\
\hline \multicolumn{2}{|c|}{ Average RSD\% } & $1.29 \%$ & & \multicolumn{2}{|c|}{ Average RSD\% } & \multicolumn{2}{|c|}{$0.77 \%$} \\
\hline \multicolumn{4}{|c|}{ Average area $=14.689 \mathrm{c}+15.188$} & \multicolumn{4}{|c|}{ Average area $=17.757 \mathrm{c}+0.3116$} \\
\hline
\end{tabular}




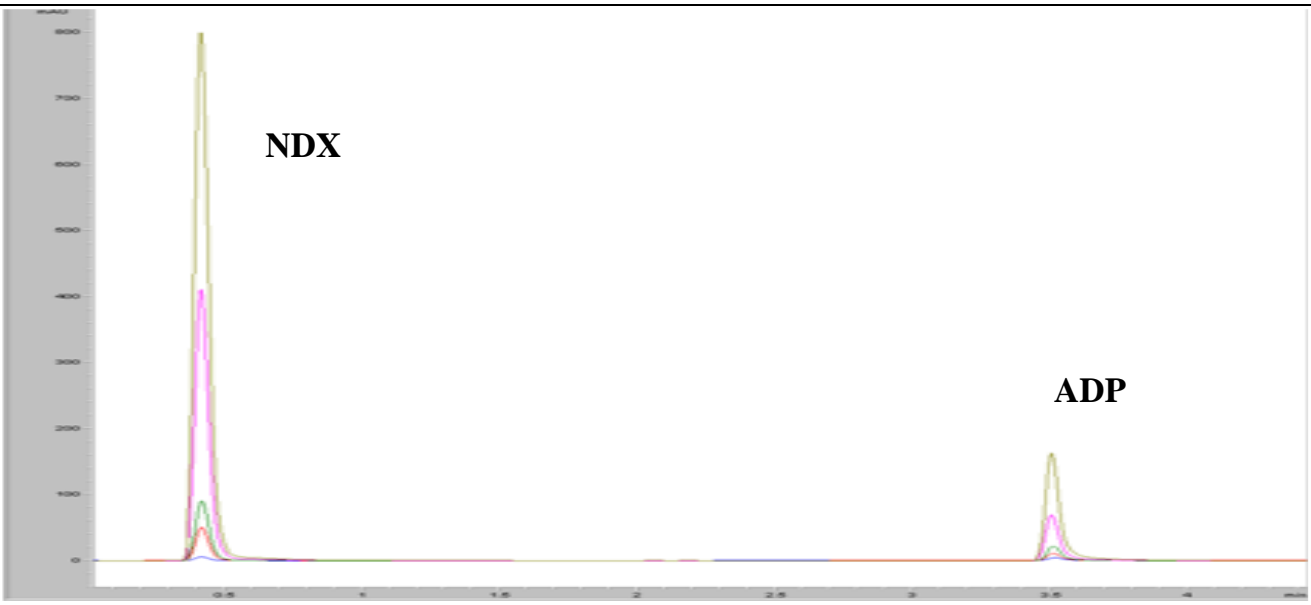

Figure 3.

Overlaid chromatograph of a mixture of five standard solutions of NDX and ADP covering the selected calibration ranges - HPLC method 2

Accuracy and precision were verified at two concentration levels. As can be seen from Table III, the method had an accuracy and precision expressed

by $\mathrm{RSD} \%$ below $1.0 \%$ and recovery ranging from 98.0 to $103.0 \%$, respectively.

Table III

Accuracy and precision results

$\begin{array}{ccc}\text { Analyte } & \mathbf{c},(\mathbf{u g} / \mathbf{m L}) & \text { Series 1 } \\ & 20 & 20.68 \\ \text { NDX } & 100 & 97.94 \\ & 5 & 4.99 \\ \text { ADP } & 15 & 15.05\end{array}$

Series 2
20.58
98.12
4.98
15.07

Concentration, $\mu \mathrm{g} / \mathrm{mL}$

Series 3 Series 4

$20.22 \quad 20.61$

$98.67 \quad 98.81$

$4.93 \quad 4.98$

15.17
15.17

$\begin{array}{cc}\text { RSD\% } & \text { Re\% } \\ 0.90 & 102.7 \\ 0.58 & 98.19 \\ 0.50 & 99.39 \\ 0.61 & 100.56\end{array}$

newly developed, three active components, topical preparations (Figures 4 and 5). The release results are not published yet. of NDX and ADP from newly developed products

The HPLC method 2 was successfully applied for the in vitro release studies of ADP and NFX from

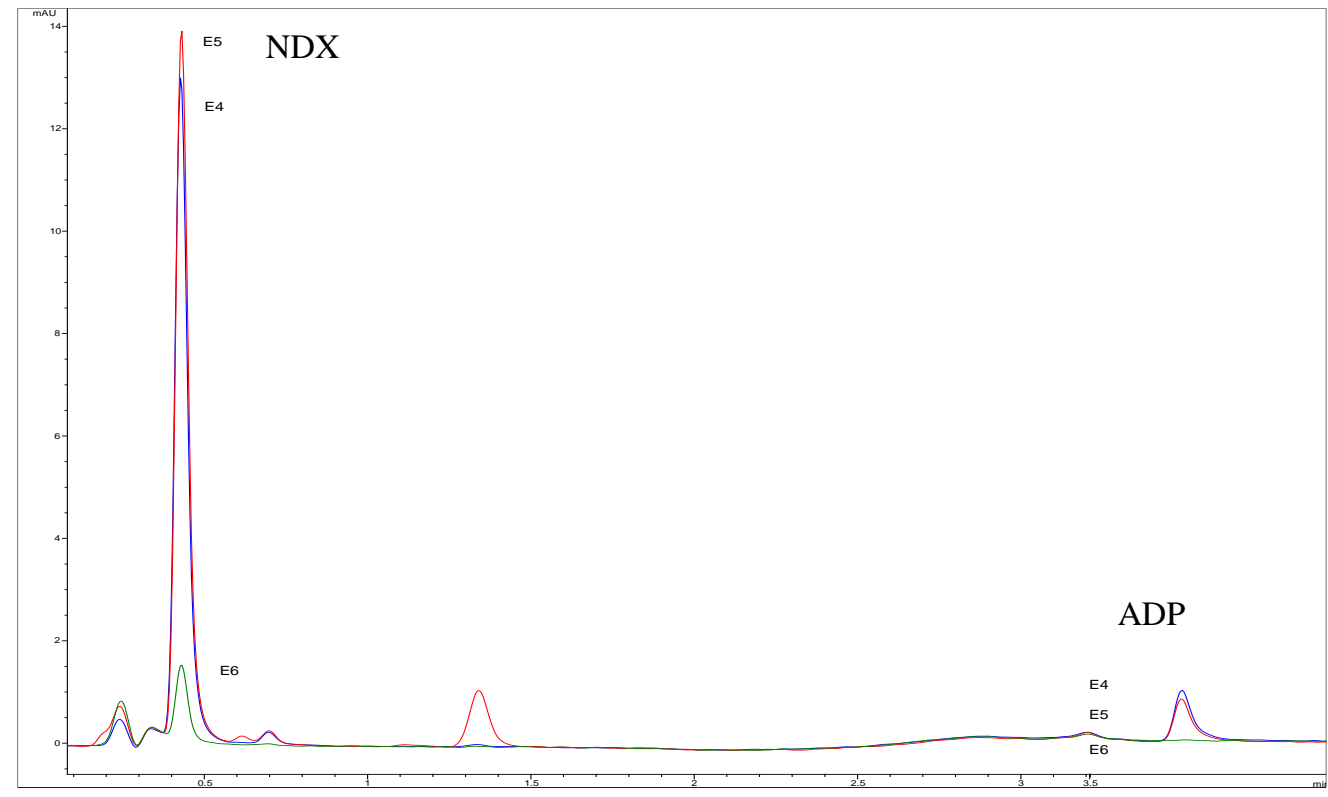

Figure 4.

Chromatograms of the receptor samples after penetration through human epidermis membrane of three newly developed topical products with NDX, ADP and GA; receptor matrix - phosphate buffer solution $(\mathrm{pH}$ 7.4):ethanol (50:50) ( $\mathrm{E}_{4}-$ HPMC gel, $\mathrm{E}_{5}-$ HEC gel, $\mathrm{E}_{6}$ - oil-in-water cream) 


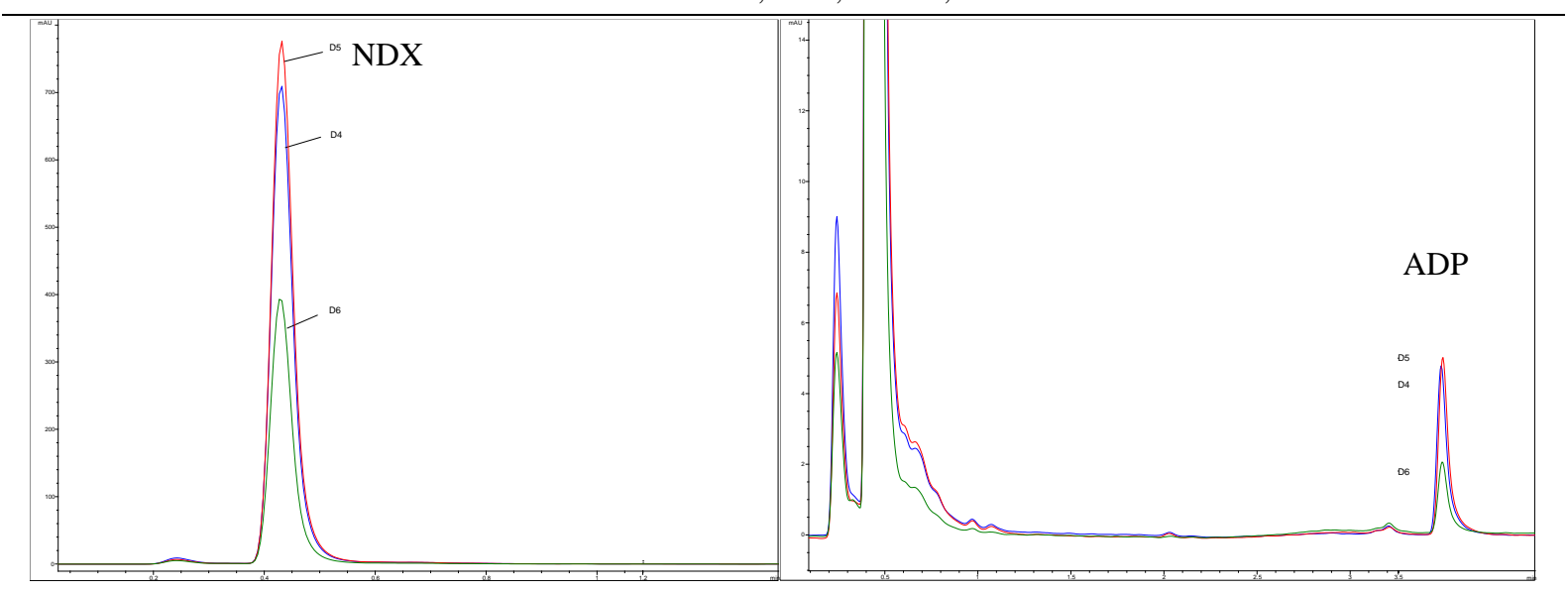

Figure 5.

Chromatograms of the receptor samples after penetration through dialysis membrane of three newly developed topical products with NDX, ADP and GA; receptor matrix - phosphate buffer solution (pH 7.4):ethanol (50:50)

$\left(\mathrm{D}_{4}-\mathrm{HPMC}\right.$ gel, $\mathrm{D}_{5}-\mathrm{HEC}$ gel, $\mathrm{D}_{6}$ - oil-in-water cream)

\section{Conclusions}

Simultaneous separation of GA, NDX and ADP from simple matrix by reversed-phase HPLC-UV is not an easy task due to their very different chromatographic behaviour, from very low to strong retained molecules. GA concentrations obtained during in vitro release studies from topical preparations through membranes could not be quantified by HPLC-UV classical reversed phase method. Therefore, a fast HPLC-UV method for simultaneous determination of NDX and ADP in the presence of GA, released through different types of membranes from fixed combinations, was finally developed. The method proved to be specific, linear, precise and it has accuracy over the selected concentration ranges.

\section{References}

1. Al Hussein SM, Evaluation of new drug formulations for topical use in acne pathology. Dermato-cosmetic procedures and dietary factors as adjuvant nonpharmacological methods. Ph thesis, University of Medicine and Pharmacy from Târgu Mureș, Romania, 2017, (available in Romanian).

2. Alba V, Urban E, Dominguez A, Nagy E, Nord CE, Palacín C, Vila J, In vitro activity of nadifloxacin against several Gram-positive bacteria and analysis of the possible evolution of resistance after 2 years of use in Germany. Int J Antimicrob Agents, 2009; 33(3): 272-275.

3. Al-Talib H, Al-Khateeb A, Hameed A, Murugaiah C, Efficacy and safety of superficial chemical peeling in treatment of active acne vulgaris. An Bras Dermatol., 2017; 92(2): 212-216.

4. Andersen FA, Cosmetic Ingredient Review Panel, Final Report on the Safety Assessment of Glycolic Acid, Ammonium, Calcium, Potassium, and Sodium Glycolates, Methyl, Ethyl, Propyl, and Butyl Glycolates, and Lactic Acid, Ammonium, Calcium, Potassium, Sodium, and TEA-Lactates, Methyl, Ethyl, Isopropyl, and Butyl Lactate, and Lauryl, Myristyl, and Cetyl Lactates. Int J Toxicol., 1998; 17(1): 1-241.

5. Chang ML, Chang CM, Simultaneous HPLC determination of hydrophilic whitening agents in cosmetic products. J Pharm Biomed Anal., 2003; 33: 617-626

6. Fox L, Csongradi C, Aucamp M, du Plessis J, Gerber M, Treatment modalities for acne. Molecules, 2016; 21(8) pii: E1063: 1-20.

7. Gieler U, Gieler T, Kupfer JP, Acne and quality of life - impact and management. J Eur Acad Dermatol., 2015, 29(4): 12-14.

8. Grigorovici A, Cherciu MS, Popescu CM, Ciobanu Apostol DG, Preda C, Călin A, Aelenei P, Efficacy and safety of Regen-Sil ${ }^{\circledR}$ in post-operative scars management. Farmacia, 2017; 65(1): 29-39.

9. Gurgu H, Ștefănescu E, Nuță DC, Căproiu MT, Dumitrașcu F, Chifiriuc MC, Bleotu C, Nițulescu GM, Rădulescu FS, Limban C, N-(1-Adamantyl carbamothioyl)benzamides: synthesis, biological evaluation and ADME predictions. Farmacia, 2018; 66(6): 963-971.

10. Jacobs MR, Appelbaum PC, Nadifloxacin a quinolone for topical treatment of skin infections and potential for systemic use of its active isomer, WCK 771. Exp Opin Pharmacother., 2006; 14: 1957-1966.

11. Kobayashi M, Nakagawa T, Fukamachi K, Nakamura M, Tokura Y, Efficacy of combined topical treatment of acne vulgaris with adapalene and nadifloxacin: A randomized study. J Dermatol., 2011; 38: 1163-1166.

12. Le Cleach L, Lebrun-Vignes B, Bachelot A, Beer F, Berger P, Brugère $S$, Chastaing M, Do-Pham G, Ferry T, Gand-Gavanou J, Guigues B, Join-Lambert O, Henry P, Khallouf R, Lavie E, Maruani A, Romain O, Sassolas B, Tran VT, Guillot B, French Acne Guidelines Working Group and Centre of Evidence of Dermatology Guidelines for the management of acne: recommendations from a French multidisciplinary group. Br J Dermatol., 2017; 177(4): 908-913.

13. Loss MJ, Leung S, Chien A, Kerrouche N, Fischer AH, Kang S, Adapalene 0.3\% gel shows efficacy for the treatment of atrophic acne scars. Dermatol Ther (Heidelb.), 2018; 8(2): 245-257. 
FARMACIA, 2019, Vol. 67, 6

14. Martins LA, Meneghini LZ, Junqueira CA, Ceni DC, Bergold AM, A simple HPLC-DAD method for determination of adapalene in topical gel formulation. J Chromatogr Sci., 2011; 49(10): 796-800.

15. Murthy AR, Babu KR, Vekariya NA, Analytical method development and validation of nadifloxacin by high performance liquid chromatography. Int $J$ Pharm Sci., 2014; 6(9): 344-346.
16. Tang SC, Yang JH, Dual effects of alpha-hydroxy acids on the skin. Molecules, 2018, 23(4). pii: E863: $1-12$.

17. Williams HC, Dellavalle RP, Garner S, Acne vulgaris. Lancet, 2012; 379: 361-372. 